\title{
Dynamics of small-sized Cladocera and their algal diet in lake with toxic cyanobacterial water blooms
}

\author{
Michał Solis ${ }^{1, *}$, Barbara Pawlik-Skowrońska ${ }^{2},{\text { Małgorzata Adamczuk }{ }^{2} \text { and Renata Kalinowska }}^{3}$ \\ ${ }^{1}$ Department of Botany and Hydrobiology, The John Paul II Catholic University of Lublin, Konstantynów 1H, 20-708 Lublin, Poland \\ 2 Department of Hydrobiology and Protection of Ecosystems, University of Life Sciences in Lublin, Dobrzańskiego 37, 20-262 Lublin, \\ Poland \\ ${ }^{3}$ Centre for Ecological Research P.A.S., Experimental Station, Niecała 18, 20-080 Lublin, Poland
}

Received: 8 October 2017; Accepted: 15 January 2018

\begin{abstract}
Species composition and quantitative structure of small-sized Cladocera community and their algal diet before, during and after cyanobacterial blooms were studied in highly eutrophic lake. The objective of the study was to investigate, how the mass development of toxin-producing cyanobacteria affect the abundances of small-sized Cladocera and their preferences within consumed algal cells. Cyanobacterial blooms were predominantly constituted by microcystin-producing genera Planktothrix, Dolichospermum, Microcystis. The concentration of intracellular microcystins in lake water ranged $0.0-23.61 \mu \mathrm{g} \mathrm{dm}{ }^{-3}$. Bosmina longirostris, B. coregonii, Diaphanosoma brachyurum and Daphnia cucullata were dominant in Cladocera community. The highest abundances of $B$. longirostris occurred in periods without cyanobacterial blooms and $B$. coregonii during blooms and after them. The maximum abundances of $D$. cucullata were observed before and after the cyanobacterial blooms, while the abundance of $D$. brachyurum was the highest at the beginning of blooms. Small Bacillariophyceae, small Chlorophyceae and Cryptophyceae were the most abundant among identified algal cells detected in digestive tracts of the Cladocera dominants. Tracts of $D$. cucullata, B. longirostris and B. coregonii contained the highest number of Bacillariophyceae always before blooms. During cyanobacterial blooms, cells of small Chlorophyceae predominated in tracts of $D$. cucullata. After bloom, cells of Cryptomonas spp. were mainly consumed both by D. cucullata and by $B$. coregonii. Fragments of Dolichospermum spp., besides Bacillariophyceae and Cryptomonas spp. cells, were occasionally found in tracts of $D$. brachyurum. Our study indicated that blooms constituted by toxinproducing cyanobacteria may influence quantitative and qualitative structure of the small-sized Cladocera community.
\end{abstract}

Keywords: Small Cladocera / algal diet / cyanobacterial blooms / shallow lakes

\section{Introduction}

Cyanobacterial blooms are increasingly common worldwide, and frequency as well as magnitude of blooms are associated with progress in water eutrophication and global warming (Pearl and Otten, 2013). Cyanobacterial blooms indicate adverse changes in aquatic ecosystems and deterioration of water quality (Tango and Butler, 2008). Toxinproducing taxa are especially harmful because cyanotoxins cause contamination of drinking water, intoxication of animals and threat to human health (Dietrich and Hoeger, 2005; Trinchet et al., 2013; Toporowska et al., 2014; Bownik, 2016).

\footnotetext{
*Corresponding author: solekmic@gmail.com
}

Ecologically, the high biomass of cyanobacteria is a sign of disruption in a food web of lake ecosystem; it causes an inhibition of transfer of primary production to higher trophic level (Ger et al., 2014). Compared to other phytoplankters, cyanobacteria have three attributes which can make them unsuitable as food for zooplankters. Cyanobacteria that form large colonies may disrupt filtration process and cause clogging of filter camera (DeMott et al., 2001), although some Cladocera can graze on cyanobacteria (Oberhaus et al., 2007; Tõnno et al., 2016). Cyanobacteria are a poor food due to their deficit in sterols and polyunsaturated fatty acids important for metabolism of animals (Wacker and Martin-Creuzburg, 2007). Cells of cyanobacteria may contain toxins such as microcystins, anatoxins-a, saxitoxins and other secondary metabolites which are lethal or sub-lethal for zooplankton (Herrera et al., 2015). Prolonged exposure time of zooplankton 

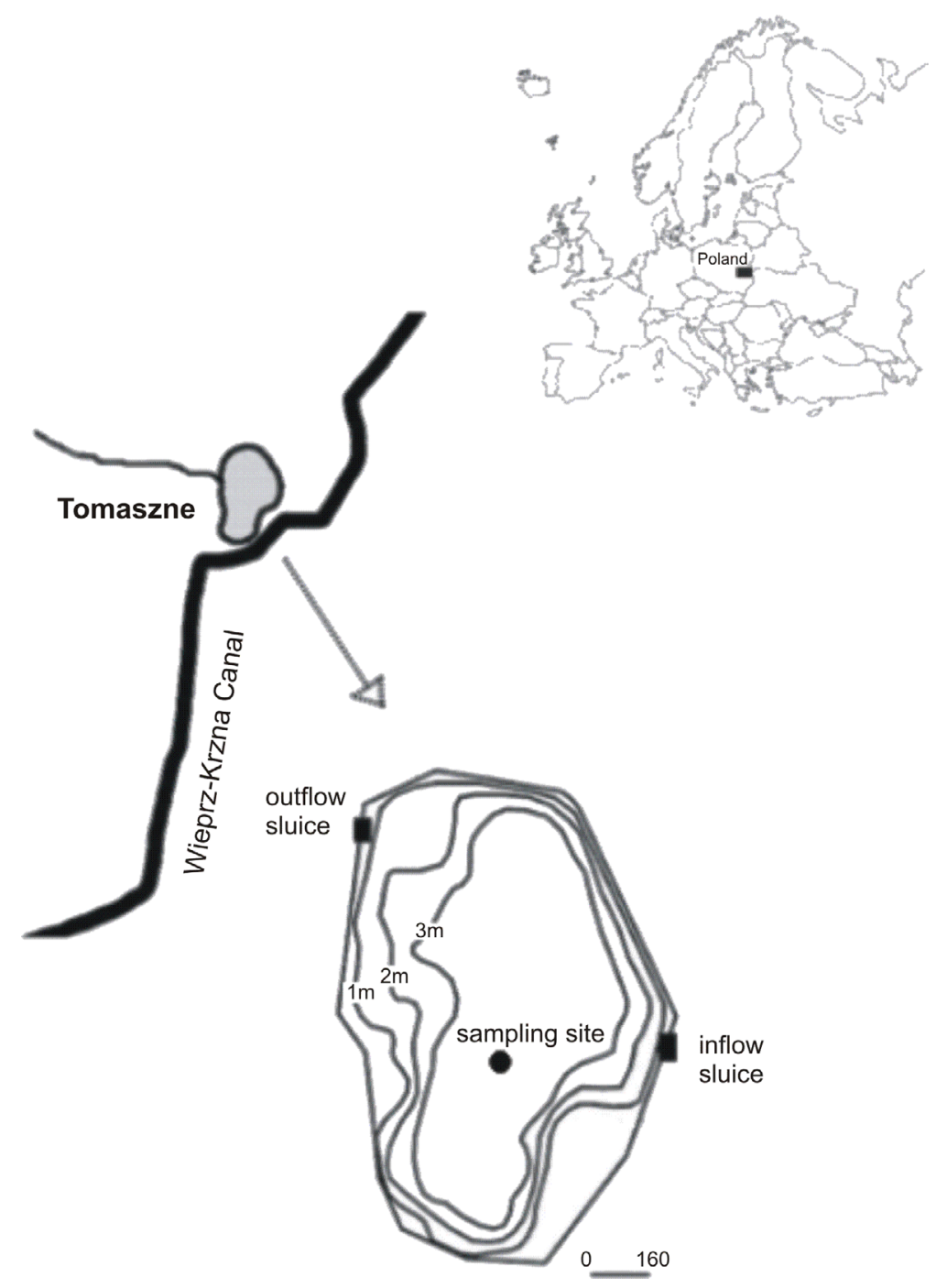

Fig. 1. Map with the location of Lake Tomaszne.

to blooms of cyanobacteria may result in selection of species with higher tolerance and/or in induction of various physiological and behavioral responses (Ger et al., 2014). As reported by Lacerot et al. (2013) and Lin et al. (2013), small-sized Cladocera predominate in zooplankton in nutrient-rich water bodies with cyanobacterial blooms. Selective grazing is a key adaptation of small Cladocera to coexist with cyanobacterial blooms. Filter-feeder species restrict the absorption of colonial cyanobacteria because they have filter camera of smaller size (Ka et al., 2012). As suggested by Infante and Riehl (1984), and Kirk and Gilbert (1992), small-sized Cladocera can develop a stronger tolerance for cyanobacterial toxins than larger Cladocera, such as some Daphnia or Diaphanosoma. This tolerance is greater for zooplankters previously exposed to the cyanobacterial blooms (Ger et al., 2014).

The main objective of this study was to investigate, how the mass development of toxin-producing cyanobacteria affect the algal diet of small-sized Cladocera subjected to heavy cyanobacterial water blooms in highly eutrophic lake. We hypothesized that toxic cyanobacterial blooms can influence both Cladocera dynamics and their diet.

\section{Study area}

Lake Tomaszne $\left(51^{\circ} 28^{\prime} 27^{\prime \prime} \mathrm{N}, 23^{\circ} 0^{\prime} 7^{\prime \prime} \mathrm{E}\right)$ is the shallow $\left(\right.$ depth $_{\max }=3.1 \mathrm{~m}$, depth aver $\left._{\text {a }}=1.8 \mathrm{~m}\right)$, morphologically altered lake connected to the large system of Wieprz-Krzna Canal (Eastern Poland) (Fig. 1). The surface of lake (area $\left.=0.95 \mathrm{~km}^{2}\right)$ was enlarged due to embankment of the shoreline with a length of $3.65 \mathrm{~km}$. The main purpose of the lake is a retention of water (maximal volume $\left.=2.21 \times 10^{6} \mathrm{~m}^{3}\right)$. Two sluices were used to water exchange. Shallowness and the entrance of fertile water from canal every year support the eutrophication process of water and perennial blooms caused by various cyanobacteria (Solis, 2012; Solis et al., 2015; Pawlik-Skowrońska and Toporowska, 2016; Solis et al., 2016).

\section{Methods}

Sampling was performed biweekly in 2010 and 2011, from the beginning of April to the end of November. Water samples for phyto- and zooplankton analysis were taken with $2 \mathrm{dm}^{3}$ 


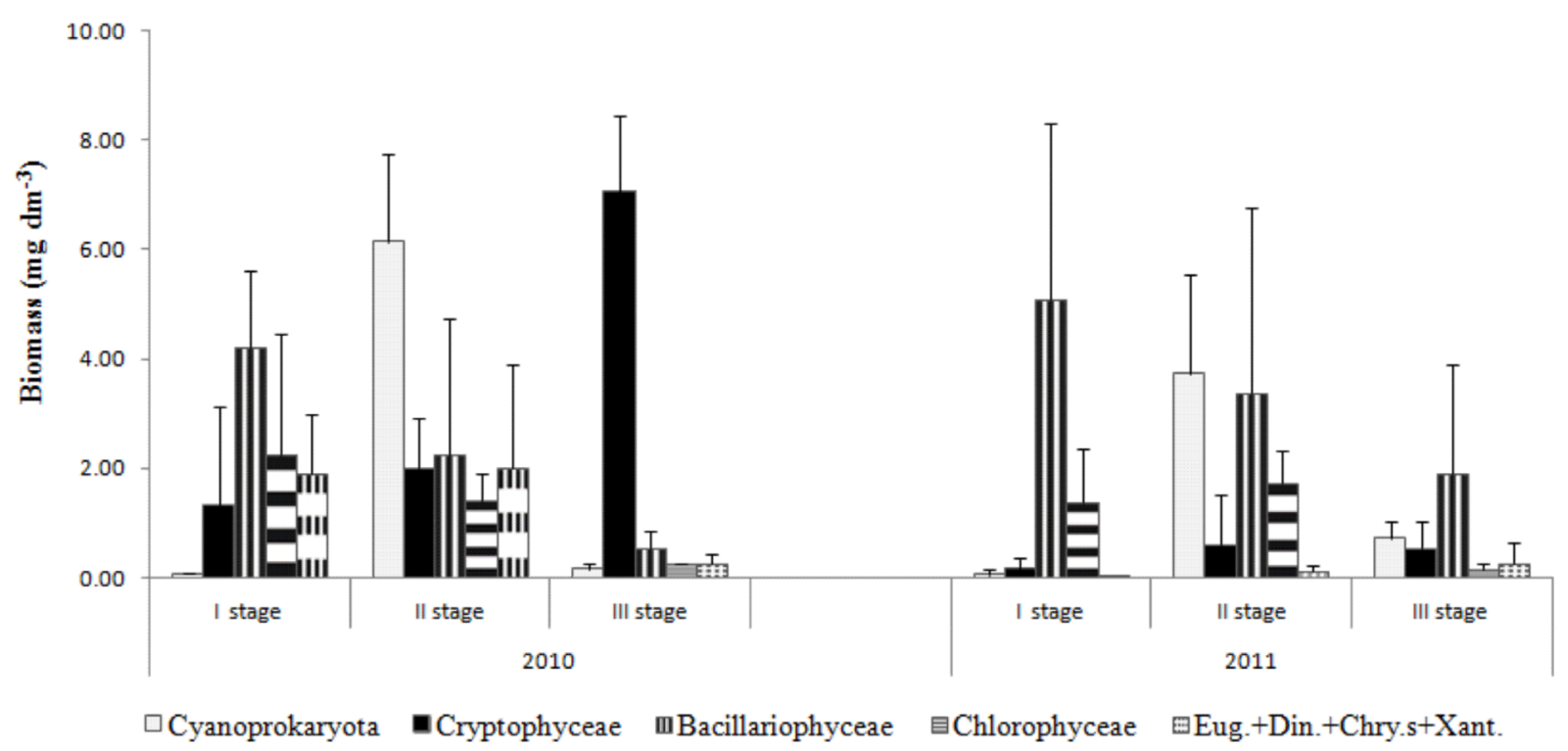

Fig. 2. Changes in biomass of phytoplankton taxonomic groups in 2010 and 2011. Data are presented as means and standard deviations (vertical bars). K-W-test: $P_{\mathrm{CYA}}=0.000, P_{\mathrm{CRY}}=0.061, P_{\mathrm{BAC}}=0.009, P_{\mathrm{CHL}}=0.002, P_{\mathrm{E}+\mathrm{D}+\mathrm{Chr}+\mathrm{Xan}}=0.002$.

Ruttner sampler (Hydrobios) from water column of the middle part of the lake, from the surface to $1.5-2.5 \mathrm{~m}$ at half-meter intervals and integrated. For phytoplankon analysis, the subsample of $150 \mathrm{ml}$ was taken from every integrated sample. For zooplankton analysis, $10 \mathrm{dm}^{3}$ of lake water was taken with sampler twice from every depth and next concentrated to 50$100 \mathrm{ml}$ with plankton net ( $35 \mu \mathrm{m}$ mesh size). Prior to fixation, planktonic animals were anesthesized by adding carbonated water to prevent regurgitation (Elbourn, 1966; Gannon and Gannon, 1975). All samples were fixed with Lugol's solution.

Phytoplankton abundance was evaluated using $5 \mathrm{~cm}^{3}$ sedimentation chamber under an inverted microscope (Zeiss Axiovert 135) (EN 15204:2006). During cyanobacterial blooms, very abundant samples were diluted up to 4 times. At least 400 individuals, treated as single cells, colonies or filaments $(100 \mu \mathrm{m}$ long unit), were counted at $400 \times$ magnification. Phytoplankton biomass was estimated based on measurements of cells or colonies. Appropriate geometric formulae (Hillebrand et al., 1999) were used to calculate a mean biovolume of cell or colony. These biovolumes were converted to biomass on the assumption, that $1 \mathrm{~mm}^{3}$ of volume equals $1 \mathrm{mg}$ of fresh-weight biomass.

Extracts of fresh cyanobacterial biomass was used to determine total intracellular microcystins (MCs) concentrations in water. Samples were filtered $\left(0.5-1 \mathrm{dm}^{3}\right.$ of water $)$ on Whatman GF/C filters and next prepared in acidified $(0.002 \mathrm{M}$ $\mathrm{HCl}$ ) $50 \%$ methanol using sonication (3 times for $5 \mathrm{~min}$., $50 \mathrm{~W}$, Sonoplus ultrasonic homogeniser, Bandelin). Extracts separation was performed on the LiChroCART 125-3 Purospher RP-18 column (125 mm, $5 \mu \mathrm{m}$, Merck). A gradient $(30-100 \%)$ of aqueous acetonitrile (Merck) acidified with $0.05 \%$ trifluoroacetic acid at a flow rate of $0.7 \mathrm{ml} \mathrm{min}^{-1}$ was used according to Lawton et al. (1994). Microcystins were detected, identified and quantified by an HPLC-photodiode array detection system (Shimadzu) using microcystin standards (Alexis Biochemicals).
Classification and counts of cladocerans were made with the use of the Sedgwick-Rafter cell to calculate abundance of each species. Identified algal cells and unidentified particles were counted in prepared digestive tracts of Cladocera dominants. Single individuals were transferred onto slides to which a drop of $6 \%$ sodium hypochlorite was added to dissolve soft tissues and improve identification of tract content (Infante, 1978). In each sample, tracts of 30 individuals were analyzed or at least 10 when they were less numerous. The cells with clearly visible diagnostic features were regarded as algae, while other, like heavily digested cells or particles of detritus, were classified as unidentified particles.

A Kruskal-Wallis test was performed to identify significant differences $\left(P_{\mathrm{K}-\mathrm{W}}<0.05\right)$ between the mean values. Calculations were made with Statistica 7.0 software.

\section{Results}

\subsection{Seasonal composition of phytoplankton and zooplankton}

Blooms of cyanobacteria were a key factor for seasonal changes of biomass of taxonomic phytoplankton groups (Fig. 2). In both years of study, three stages in every year were distinguished: before cyanobacterial bloom (stage I: 10.04 $30.06,2010$ and 12.04-22.06, 2011), during cyanobacterial bloom (stage II: 14.07-22.09, 2010 and 8.07-5.10, 2011) and after cyanobacterial bloom (stage III: 6.10-18.11, 2010 and 19.10-18.11, 2011).

Before cyanobacterial blooms (stage I), phytoplankton biomass was dominated by Bacillariophyceae with two dominant species Fragilaria acus $\left(0.05-1.53 \mathrm{mg} \mathrm{dm}^{-3}\right.$ in 2010 and $0.07-8.43 \mathrm{mg} \mathrm{dm}^{-3}$ in 2011) and Stephanodiscus hantzschii $\left(0.09-1.67 \mathrm{mg} \mathrm{dm}^{-3}\right.$ in 2010 and $0.02-2.90 \mathrm{mg}$ $\mathrm{dm}^{-3}$ in 2011). Puncticulata balatonis co-dominated with those taxa in $2011\left(0.10-8.82 \mathrm{mg} \mathrm{dm}^{-3}\right)$. 
Table 1. Differences in the biomass of the toxigenic cyanobacteria and microcystins' concentrations over the vegetative seasons in highly eutrophic Lake Tomaszne.

\begin{tabular}{|c|c|c|c|c|c|c|c|c|}
\hline & & \multicolumn{2}{|l|}{$\underline{\text { Stage I }}$} & \multicolumn{2}{|l|}{$\underline{\text { Stage II }}$} & \multicolumn{2}{|l|}{ Stage III } & $P_{\mathrm{KW}}$ \\
\hline Total toxigenic cyanobacteria & $\mathrm{mg} \mathrm{dm}{ }^{-3}$ & $0.03-0.12$ & $0-0.18$ & $3.54-7.82$ & $1.30-5.65$ & $0.07-0.30$ & $0-0.66$ & $0.000^{*}$ \\
\hline Planktothrix agardhii & $m g \mathrm{dm}^{-3}$ & $0.06-0.012$ & $0-0.14$ & $0.07-6.66$ & $0.54-5.44$ & $0.04-0.19$ & $0-0.60$ & $0.001 *$ \\
\hline Aphanizomenon gracile & $m g \mathrm{dm}^{-3}$ & $0-0.01$ & $<0.01$ & $0.15-5.84$ & $0.01-1.28$ & $0-0.11$ & $0-0.02$ & $0.000 *$ \\
\hline Dolichospermum spp. & $\mathrm{mg} \mathrm{dm}^{-3}$ & $<0.01$ & $0-0.02$ & $0.03-4.55$ & $0-0.74$ & $<0.01$ & $<0.01$ & $0.007^{*}$ \\
\hline
\end{tabular}

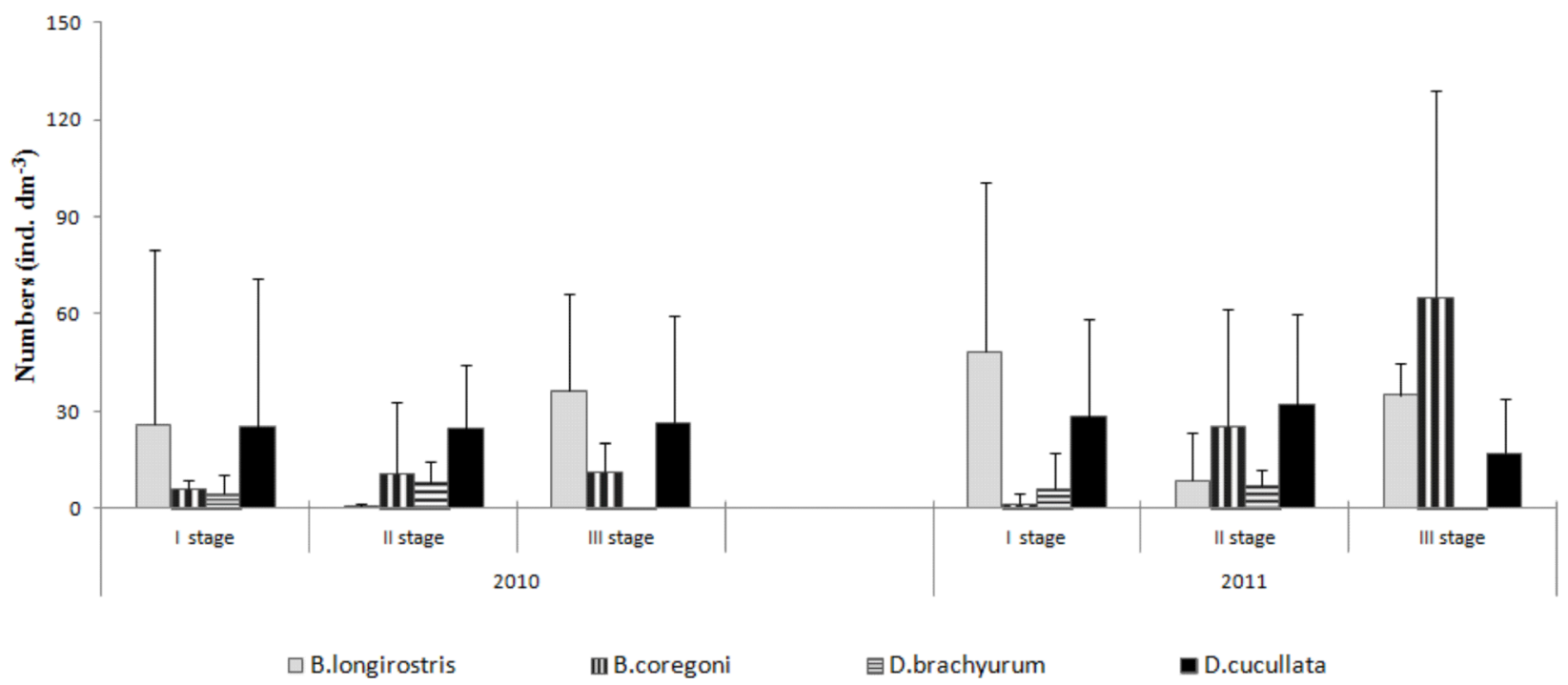

Fig. 3. Abundance of Cladocera dominant in Lake Tomaszne in 2010 and 2011. Data are presented as means and standard deviations (vertical bars). K-W-test: $P_{\mathrm{B} . \text { long }}=0.050, P_{\mathrm{B} . \text { coreg }}=0.001, P_{\mathrm{D} . \text { brach }}=0.066, P_{\mathrm{D} . \text { cuccl }}=0.667$.

In stage II, cyanobacterial water blooms were formed by 22 potentially toxin-producing taxa, like Microcystis spp., Dolichospermum spp., Aphanizomenon spp,. Planktothrix spp., Planktolyngbya spp., and Limnothrix spp., whose total biomass ranged from 1.3 to $8.1 \mathrm{mg} \mathrm{dm}^{-3}$ (Tab. 1). Among them 15 species of cyanobacteria were potential microcystinsproducers. Planktothrix agardhii (Oscillatoriales) was the main constituent of blooms and its biomass ranged similarly in both years (2010: $0.07-6.66 \mathrm{mg} \mathrm{dm}^{-3}, 2011$ : $0.54-5.44 \mathrm{mg}$ $\left.\mathrm{dm}^{-3}\right)$. Two species of Nostocales Aphanizomenon gracile (max. biomass $5.84 \mathrm{mg} \mathrm{dm}^{-3}$ ) and D. planktonicum (max. biomass $5.52 \mathrm{mg} \mathrm{dm}^{-3}$ ) co-dominated with $P$. agardhii in 2010. Also some Bacillariophyceae constituted significantly phytoplankton biomass in 2011, primarily $F$. acus (max. biomass $4.88 \mathrm{mg} \mathrm{dm}^{-3}$ ). Concentrations of intracellular microcystins in lake water (Tab. 1) during cyanobacterial blooms (2010: 14.13-23.61 $\mu \mathrm{g} \mathrm{dm}^{-3}, \quad 2011$ : 2.18-23.02 $\mathrm{g} \mathrm{dm}^{-3}$ ) were significantly higher $\left(P_{\mathrm{K}-\mathrm{W}}=0.000\right)$ than before blooms (2010: $\left.0-2.43 \mu \mathrm{g} \mathrm{dm}^{-3}, 2011: 0-1.69\right)$ and after them (2010: 0-10.22 $\mathrm{g} \mathrm{g} \mathrm{dm}^{-3}$, 2011: not detected).

After cyanobacterial blooms (stage III), Cryptophyceae or Bacillariophyceae predominated in phytoplankton biomass (Fig. 2). Mass development of Cryptomonas spp. (5.6-
$8.8 \mathrm{mg} \mathrm{dm}^{-3}$ ) was noted in 2010. Next year, S. hantzschii and $F$. acus constituted high biomass of Bacillariophyceae. Chlorophyceae with dominant Oocystis lacustris, Coelastrum spp., Scenedesmus spp., Planctonema lauterbornii (Ulvophyceae), Euglena spp. (Euglenophyceae) and Cryptomonas spp. (Cryptophyceae) were always less abundant in both years.

Cladocera community in the lake was exclusively composed of small-sized species (body length $<1 \mathrm{~mm}$ ): Bosmina longirostris, B. coregonii, Chydorus sphaericus, Diaphanosoma brachyurum, Daphnia cucullata, Alona rectangula, A. costata, Ceriodaphnia quadrangula. Total abundance of Cladocera varied from 2 to $205 \mathrm{ind} . \mathrm{dm}^{-3}$ within 2years study (Fig. 3). Abundance of four species B. longirostris, $B$. coregonii, D. brachyurum, D. cucullata accounted for 82 $100 \%$ of the total abundance of Cladocera (Fig. 3). The abundance of $B$. longirostris was significantly higher in periods without cyanobacterial blooms (stages I and III), with peaks observed in the first half of May (2010: 122 ind. $\mathrm{dm}^{-3}$; 2011: 135 ind. $\mathrm{dm}^{-3}$ ). In turn, abundance of $B$. coregonii increased clearly in 2011 during cyanobacterial blooms (stage II) and after them (stage III); two peaks were observed in October 2010 and 2011 (110 and 135 ind. $\mathrm{dm}^{-3}$, respectively). Significant differences in abundance of $D$. cucullata between 
Table 2. Comparison of dominant Cladocera digestive tracts and their content.

\begin{tabular}{|c|c|c|c|c|c|c|}
\hline \multirow[b]{2}{*}{2010} & \multicolumn{2}{|c|}{ Stage I } & \multicolumn{2}{|c|}{ Stage II } & \multicolumn{2}{|c|}{ Stage III } \\
\hline & 2011 & 2010 & 2011 & 2010 & 2011 & \\
\hline Number of empty digestive tracts & 32 & 37 & 44 & 77 & 37 & 37 \\
\hline Number of identified algal cells & 165 & 306 & 95 & 86 & 181 & 35 \\
\hline Number of unidentified particles & 176 & 518 & 773 & 1087 & 1192 & 430 \\
\hline
\end{tabular}

\section{Bosmina longirostris}
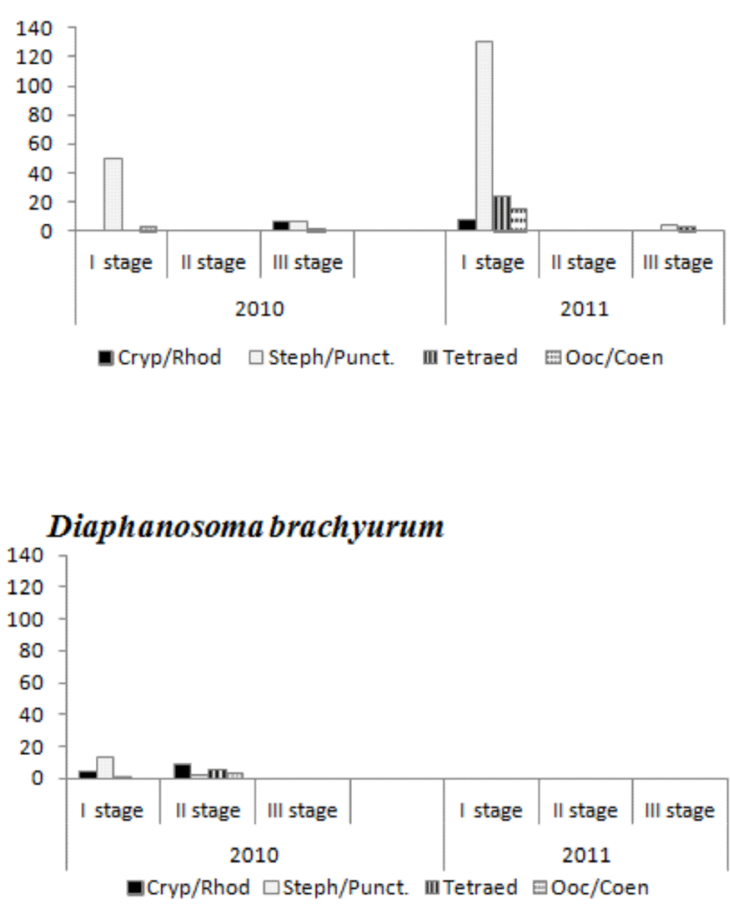

\section{Bosmina coregoni}

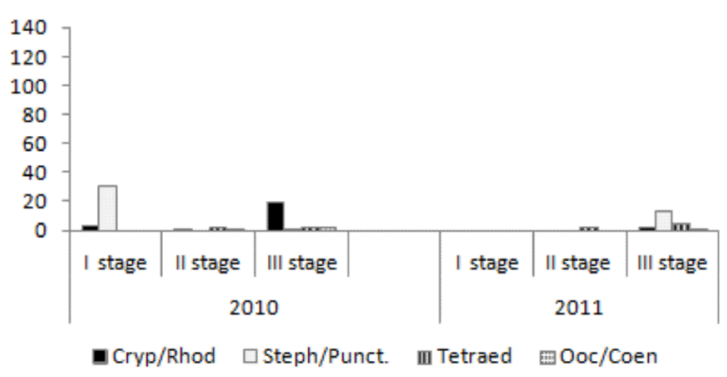

Daphnia cucullata

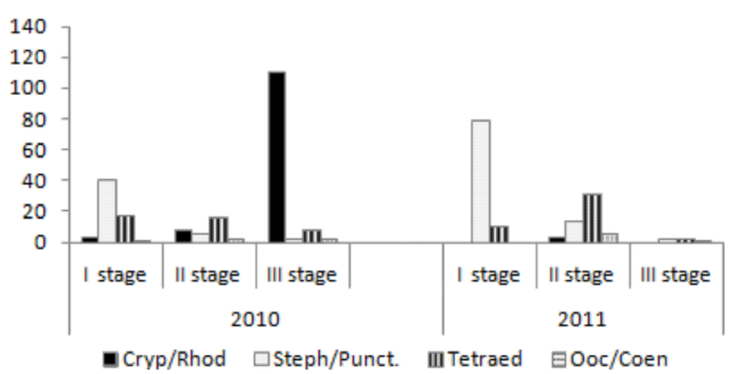

Fig. 4. Number of algal cells in digestive tracts of quantitatively dominant Cladocera in different stages of cyanobacterial bloom occurrence. Cryp/Rhod-Cryptomonas/Rhodomonas, Steph/Punct-Stephanodiscus/Puncticulata, Tetraed-Tetraedron, Ooc/Coen-Oocystis/Coenococcus.

the distinguished stages of phytoplankton development were not found. However, the maximum numbers of D. cucullata were observed before, e.g. in the second half of June (2010: 105 ind. $\mathrm{dm}^{-3} ; 2011: 75$ ind. $\mathrm{dm}^{-3}$ ) and after the cyanobacterial blooms in the first decade of October (2010: 72 ind. $\mathrm{dm}^{-3}$; 2011: 98 ind $\mathrm{dm}^{-3}$ ). The abundance of $D$. brachyurum was the highest in July 2010 (27 ind. $\mathrm{dm}^{-3}$ ) and in June 2011 $\left(10\right.$ ind $\left.\mathrm{dm}^{-3}\right)$, at the beginning of cyanobacterial blooms.

\subsection{Content of digestive tracts of Cladocera}

Both algal cells and unidentified particles were detected and counted in 1167 digestive tracts of dominant Cladocera. Analysis were done in 498 tracts of D. cucullata (empty 106), in 295 tracts of $B$. longirostris (empty 70), in 217 tracts of $B$. coregonii (empty 66) and in 157 tracts of $D$. brachyurum (empty 22). The number of filled guts was greater during cyanobacterial blooms than in other two stages (Tab. 2). Before cyanobacterial blooms (stage I), algal cells accounted for $43 \%$
(2010) and 37\% (2011) of the total number of unidentified particles and algal cells. During cyanobacterial blooms (stage II) and after them (stage III), identified algal cells accounted only for $7-13 \%$ of the total number of grazed particles.

In the algal cells and colonies found in all digestive tracts of Cladocera, small centric Bacillariophyceae P. balatonis, $S$. hantzschii, Fragilaria spp., and fragments of colonies of Aulacoseira granulata contributed in 47\%, small Chlorophyceae Tetraedron minimum and T. triangulare, O. lacustris, Quadrigula spp., Coelastrum spp., Monoraphidium spp., Scenedesmus spp. and Chlamydomonas spp. in 27\%, while Cryptophyceae Cryptomonas spp. and Rhodomonas spp. in $22 \%$. In $3.5 \%$ of all digestive tracts, short fragments of filaments (2-3 cell) of Dolichospermum planctonicum (syn. Anabaena planctonica), cells of Euglena spp. and Trachelomonas spp. (Euglenophyceae) and empty lorici of Dinobryon spp. (Chrysophyceae) were also found (1-5 cells per digestive tract).

Distribution of the most frequently found algal cells in digestive tracts of small-sized dominant Cladocera is presented in Figure 4. Before cyanobacterial blooms (stage I), tracts of $D$. 
cucullata and B. longirostris contained cells of the centric Bacillariophyceae: Stephanodiscus spp. and P. balatonis in the numbers significantly higher than those occurring during other stages of phytoplankton development $\left(P_{\mathrm{K}-\mathrm{W}}=0.014\right)$. In $B$. coregonii tracts, cells of Stephanodiscus spp. and Puncticulata spp. were found before cyanobacterial bloom in 2010 and after the bloom in 2011 in lower numbers than in B. longirostris and D. cucullata. During cyanobacterial blooms (stage II), algal cells (T. minimum, Oocystis spp. and Coenococcus spp.) were mostly found in digestive tracts of D. cucullata. These taxa accounted for $>60 \%$ of all algal cells. However, Chlorophyceae were not detected or in very low amounts in tracts of other Cladocera. After cyanobacterial bloom in 2010 (stage III), cells of Cryptomonas spp. were mainly consumed both by $D$. cucullata and by B. coregonii and cryptophytes accounted for $89 \%$ and $76 \%$ of all algal cells, respectively. The lowest numbers of algal cells were found in digestive tracts of $D$. brachyurum over the whole study period. Fragments of $D$. planctonicum were detected in its tract only during cyanobacterial blooms (stage II), besides Bacillariophyceae, Chlorophyceae and Cryptophyceae cells.

\section{Discussion}

Small-sized cladocerans often prevail in Crustacean communities in highly eutrophic water bodies (Haberman et al., 2007). In the Lake Tomaszne, Cladocera populations with body length below $1 \mathrm{~mm}$ was constituted mainly by Daphnia, Bosmina, Diaphanosoma and Chydorus. The high pressure of fish community (the lake is stocked each year) and development of cyanobacterial blooms prevent the growth of larger cladocerans (Iglesias et al., 2011; Jiang et al., 2014).

One of the most important environmental factor controlling zooplankton dynamics is supply of edible phytoplankton (Sommer et al., 1986; Abrantes et al., 2009). Laboratory experiments are useful in getting information on particular grazer and algal species relationships such as feeding preferences, grazer resistance and toxicity (Kerfoot and Kirk, 1991; Soares et al., 2009). In natural systems, however, zooplankton feeding and selectivity may depend on the relative availability of different food sources (Levine et al., 1999; Deng et al., 2008).

In our study, small Cladocerans have clear preferences for cryptophytes, diatoms and chlorophytes, which had dimensions below $30 \mu \mathrm{m}$. The cells of diatoms and cryptophytes were most abundant in digestive tracts of $B$. longirostris, $B$. rostrata and $D$. cucullata, in periods before and after cyanobacterial blooms. According to Tõnno et al. (2016), Bosmina and Daphnia showed selectivity for chlorophytes and diatoms over other algal groups. Thys et al. (2003) suggest that cryptophytes are preferred algae for cladocerans. Lipid and fatty acid composition is considered to be a key parameter that determines the nutritive quality of algal food for zooplankton (Wichard et al., 2007). Cryptophytes contain higher, than diatoms, content of the polyunsaturated fatty acids: EPA and DHA (Ahlgren et al., 1990; Taipale et al., 2012).

During cyanobacterial blooms cladocerans showed high selectivity for algal food. Tracts of $B$. longirostris, $B$. rostrata and $D$. cucullata contained significantly less identified algal cells than in two stages without cyanobacterial blooms, but small-sized cryptophytes, diatoms and chlorophytes still dominated. Small Daphnia, Diaphanosoma and Chydorus are feeders with size and prey-type selection (Hopp et al., 1997). Kerfoot and Kirk (1991) demonstrated that small Daphnia, Diaphanosoma and Chydorus consumed algal foods by size and some taste selectivity, whereas $B$. longirostris had clearly revealed taste discrimination. Fulton and Paerl (1987) showed that unicellular forms of phytoplankton are generally better ingested by $B$. longirostris than colonial forms. Both $B$. longirostris and $B$. coregonii have filter apparatus with meshsize below $1.6 \mu \mathrm{m}$ and thus they have preferences to small algae, bacteria and detritus (Straile and Müller, 2010).

In our studies, also fragments of Dolichospermum trichoms were occasionally found in tracts of $D$. brachyurum during cyanobacterial bloom, however, it should not be excluded that small Cladocera consumed cyanobacterial cells in higher quantity but they were unrecognizable after digestion. During blooms, near $90 \%$ of particles in tracts were unidentified. Eukaryotic algae with more persistent cell walls can be digest for longer time than cyanobacterial cells and therefore easier detected.

Cyanobacterial blooms in Lake Tomaszne were caused by species that are potential producers of microcystins (Carmichael, 2001). As reported by Solis et al. (2015), the P. agardhii and $D$. planctonicum were rather the main producers of microcystins in Tomaszne Lake. However, other microcystin producing species (e.g. Microcystis spp.) can also develop in mass in the lake (Pawlik-Skowrońska and Toporowska, 2016). Two MC variants (MC-RR and MC-LR) in the studied period were mostly associated with $P$. agardhii biomass, while the biomass of $D$. planctonicum correlated with the MC-LF, $-\mathrm{LY}$, -LR and -LA variants (Solis et al., 2015).

Several studies confirmed that total zooplankton biomass is usually negatively correlated with microcystins' concentrations (Reichwaldt et al., 2013). Numerous laboratory experiments also demonstrated that microcystins' producers can inhibit Daphnia feeding, growth and reproduction (Chislock et al., 2013; Herrera et al., 2015; Bownik, 2016). The results of our study suggest that blooms of toxin-producing cyanobacteria can exert impact on dynamics of Cladocera community. The numbers of small-sized cladocerans decreased when producers of microcystins intensively developed but still the populations of small Cladocera species coexisted with bloomforming cyanobacteria. Smaller Cladocera can develop stronger tolerance to ingested toxic cyanobacteria than larger Daphnia (Davis and Gobler, 2011; Ger et al., 2014). This tolerance is greater for cladocerans previously exposed on toxic cyanobacterial blooms (Guo and Xie, 2006). As reported by Pflugmacher et al. (1998), the longer period of blooms can cause the improvement of physiological tolerance to consumed toxic cells, with regard to more efficient detoxification mechanisms. Bosminids appear to be less affected by toxic cyanobacteria than daphnids (Jiang et al., 2013). Experiments performed by Hansson et al. (2007) showed that the biomass of small Bosmina was not affected by extracellular microcystins in water.

The permanent co-existence of small Cladocera with cyanobacterial blooms in Lake Tomaszne results from the fact that, in general, small-sized cladocerans are less affected by cyanobacteria (Davis et al., 2012). Beside the greater resistance to cyanobacterial toxins, selective feeding is a key adaptation to 
survive during cyanobacterial blooms (Davis and Gobler, 2011). Small Daphnia and Diaphanosoma have filter camera of smaller size than greater Cladocera, while Bosmina and Chydorus species are dual-mode feeders, which can combine raptorial and filter-feeding (Cyr and Curtis, 1999). They are able to feed on small eukaryotic algae, also on motile cryptophytes, and thus to avoid large toxic cyanobacteria.

\section{Conclusion}

During development of microcystin producing cyanobacteria quantitative and qualitative changes in the structure of small-sized Cladocera community was found. Blooms caused by filamentous cyanobacteria limited a consumption of high energy algal food by cladocerans. Different species of smallsized Cladocera may survive and develop during perennial cyanobacterial blooms due to their abilities to selective feeding on eukaryotic algae and resistance to cyanotoxins.

Acknowledgements. This research was financially supported by a grant from the Polish Ministry of Science and Higher Education to M. S. (No. N N305 392138).

\section{References}

Abrantes N, Nogueira A, Goncalves F. 2009. Short-term dynamics of cladocerans in a eutrophic shallow lake during a shift in the phytoplankton dominance. Ann Limnol - Int J Lim 45: 237-245.

Ahlgren G, Lundstedt L, Brett M, Forsberg C. 1990. Lipid composition and food quality of some freshwater phytoplankton for cladoceran zooplankters. J Plankton Res 12: 809-818.

Bownik A. 2016. Harmful algae: effects of cyanobacterial cyclic peptides on aquatic invertebrates - a short review. Toxicon 124: 26-35.

Carmichael WW. 2001. Health effects of toxin- producing Cyanobacteria: the CyanoHABs. Hum Ecol Risk Assess 7: 1393-1407.

Chislock MF, Sarnelle O, Jernigan LM, Wilson AE. 2013. Do high concentrations of microcystin prevent Daphnia control of phytoplankton? Wat Res 47: 1961-1970.

Cyr H, Curtis JM. 1999. Zooplankton community size structure and taxonomic composition affects size-selective grazing in natural communities. Oecologia 118: 306-315.

Davis TW, Gobler CJ. 2011. Grazing by mesozooplankton and microzooplankton on toxic and non-toxic strains of Microcystis in the Transquaking River, a tributary of Chesapeake Bay. J Plankton Res 33: 415-430.

Davis TW, Koch F, Marcoval MA, Wilhelm S, Gobler CJ. 2012. Mesozooplankton and microzooplankton grazing during cyanobacterial blooms in the western basin of Lake Erie. Harmful Algae 15: 26-35.

DeMott WR, Gulati RD, Van Donk E. 2001. Daphnia food limitation in three hypereutrophic Dutch lakes: evidence for exclusion of large-bodied species by interfering filaments of cyanobacteria. Limnol Oceanogr 46: 2054-2060.

Deng D, Xie P, Zhou Q, Hua Y, Longgen G, Hong G. 2008. Field and experimental studies on the combined impacts of cyanobacterial blooms and small algae on crustacean zooplankton in a large, eutrophic, subtropical, Chinese lake. Limnology 9: 1-11.

Dietrich D, Hoeger S. 2005. Guidance values for microcystins in water and cyanobacterial supplement products (blue-green algal supplements): a reasonable or misguided approach? Toxicol Appl Pharm 203: 273-289.

Elbourn CA. 1966. Some observations on the food of Cyclops strenuus strenuus (Fisher). Ann Mag Nat Hist 13: 227-231.

EN 15204:2006. 2000. Water quality. Guidance standard on the enumeration of phytoplankton using inverted microscopy (Utermoehl technique) 29th September 2006, European Parliament Council. Directive 2000/60/EC of the European Parliament and of the council of 23rd October 2000 establishing a framework for community action in the field of water policy. Off J Eur Commun L327: 1-72.

Fulton RS, Paerl HW. 1987. Toxic and inhibitory effects of the bluegreen-alga Microcystis aeruginosa on herbivorous zooplankton. $J$ Plankton Res 9: 837-855.

Gannon JE, Gannon SA. 1975. Observations on the narcotization of crustacean zooplankton. Crustaceana 28: 220-224.

Ger KA, Hansson LA, Lurling M. 2014. Understanding cyanobacteria-zooplankton interactions in a more eutrophic world. Fresh Biol 59: 1783-1798.

Guo NC, Xie P. 2006. Development of tolerance against toxic Microcystis aeruginosa in three cladocerans and the ecological implications. Environ Poll 143:513-518.

Haberman J, Laugaste R, Nõges T. 2007. The role of cladocerans reflecting the trophic status of two large and shallow Estonian lakes. Hydrobiologia 584: 157-166.

Hansson LA, Gustafsson S, Rengefors K, Bomark L. 2007. Cyanobacterial chemical warfare affects zooplankton community composition. Fresh Biol 52: 1290-1301.

Herrera N, Echeverri LF, Ferrão-Filho AS. 2015. Effects of phytoplankton extracts containing the toxin microcystin-LR on the survival and reproduction of cladocerans. Toxicon 95: $38-45$.

Hillebrand H, Dürselen CD, Kirschtel D, Pollingher U, Zohary T. 1999. Biovolume calculation for pelagic and benthic microalgae. $J$ Phycol 35: 403-424.

Hopp U, Maier G, Bleher R. 1997. Reproduction and adult longevity of five species of planktonic cyclopoid copepods reared on different diets: a comparative study. Freshw Biol 38: 289-300.

Iglesias C, Mazzeo N, Meerhoff M, et al. 2011. High predation is the key importance for dominance of small-bodied zooplankton in warm shallow lakes: evidence from lakes, fish exclosures and surface sediments. Hydrobiologia 667: 133-147.

Infante A. 1978. A method for the study of foods of herbivorous zooplankton. Trans Amer Micros Soc 97: 256-258.

Infante A, Riehl W. 1984. The effect of cyanophyta upon zooplankton in a eutrophic tropical lake (Lake Valencia, Venezuela). Hydrobiologia 113: 293-298.

Jiang X, Li Q, Liang H, Zhao S, Zhang L, Zhao Y. 2013. Clonal variation in growth plasticity within a Bosmina longirostris population: the potential for resistance to toxic cyanobacteria. PLOS ONE 8: e73540.

Jiang X, Yang W, Zhang L, Chen L, Niu Y. 2014. Predation and cyanobacteria jointly facilitate competitive dominance of smallbodied cladocerans. J Plankton Res 36: 956-965.

Ka S, Mendoza-Vera JM, Bouvy M, Champalbert G, N'gom-Ka R, Pagano M. 2012. Can tropical freshwater zooplankton graze efficiently on cyanobacteria? Hydrobiologia 679: 119-138.

Kerfoot WC, Kirk KL. 1991. Degree of taste discrimination among suspension-feeding cladocerans and copepods: implications for detritivory and herbivory. Limnol Oceanogr 36: 1107-1123.

Kirk KL, Gilbert JJ. 1992. Variation in herbivore response to chemical defences-zooplankton foraging on toxic cyanobacteria. Ecology 73: 2208-2217. 
Lacerot G, Kruk C, Lurling M, Scheffer M. 2013. The role of subtropical zooplankton s grazers of phytoplankton under different predation levels. Fresh Biol 58: 494-503.

Lawton LA, Edwards C, Codd GA. 1994. Extraction and high performance liquid chromatographic method for the determination of microcystins in raw and treated waters. Analyst 119: 1525-1530.

Levine SN, Borchardt MA, Braner M, Shambaugh A. 1999. The impact of zooplankton grazing on phytoplankton species composition and biomass in lake Champlain (USA-Canada). $J$ Great Lakes Res 25: 61-77.

Lin KY, Sastri AR, Gong GC, Hsieh CH. 2013. Copepod community growth rates in relation to body size, temperature, and food availability in the East China Sea: a test of metabolic theory of ecology. Biogeosciences 10: 1877-1892.

Oberhaus L, Gélinas M, Pinel-Alloul B, Ghadouani A, Humbert JF. 2007. Grazing of two toxic Planktothrix species by Daphnia pulicaria: potential for bloom control and transfer of microcystins. J Plankton Res 29: 827-838.

Pawlik-Skowrońska B, Toporowska M. 2016. How to mitigate cyanobacterial blooms and cyanotoxin production in eutrophic water reservoirs? Hydrobiologia 778: 45-59.

Pearl HW, Otten TG. 2013. Harmful cyanobacterial blooms: causes, consequences and controls. Microbial Ecol 65: 995-1010.

Pflugmacher S, Wiegand C, Oberemm A, Beattie KA, Krause E, Codd GA. 1998. Identification of an enzymatically formed glutathione conjugate of the cyanobacterial hepatotoxin microcystin-LR: the first step of detoxication. Bioch et Bioph Acta 1425: 527-533.

Reichwaldt ES, Song H, Ghadouani A. 2013. Effects of the distribution of a toxic Microcystis bloom on the small scale patchiness of Zooplankton. PLoS ONE 8: e66674.

Soares MCS, Lürling M, Panosso R, Huszar V. 2009. Effects of the cyanobacterium Cylindrospermopsis raciborskii on feeding and life-history characteristics of the grazer Daphnia magna. Ecotoxicol Environ Saf 72: 1183-1189.

Solis M. 2012. Impact of Wieprz-Krzna Canal on physical-chemical and biological characteristics in selected storage reservoirs. Inz Ekol 29: 182-191 (in Polish).

Solis M, Pawlik-Skowrońska B, Kalinowska R. 2015. Development of toxin-producing cyanobacteria during the water level manipula- tion in a shallow heavily modified lake. Oceanol Hydrobiol Stud 44: 223-235.

Solis M, Pawlik-Skowrońska B, Kalinowska R. 2016. Seasonal changes of phytoplankton and cyanobacteria/cyanotoxin risk in two shallow morphologically altered lakes: effects of water level manipulation (Wieprz-Krzna Canal System, Eastern Poland). Ecol Indic 66: 103-112.

Sommer U, Gliwicz ZM, Lampert W, Duncan A. 1986. The PEGmodel of seasonal succession of planktonic event in fresh waters. Arch Hydrobiol 106: 433-471.

Straile D, Müller H. 2010. Response of Bosmina to climate variability and reduced nutrient loading in a large lake. Limnologica 40: 92-96.

Taipale SJ, Brett MT, Pulkkinen K, Kainz MJ. 2012. The influence of bacteria-dominated diets on Daphnia magna somatic growth, reproduction, and lipid composition. FEMS Microbiol Ecol 82: 50-62.

Tango PJ, Butler W. 2008. Cyanotoxins in tidal waters of Chesapeake Bay. Northeast Nat 15: 403-416.

Thys I, Leporcq B, Descy J-P. 2003. Seasonal shifts in phytoplankton ingestion by Daphnia galeata, assessed by analysis of marker pigments. J Plankton Res 25: 1471-1484.

Tõnno I, Agasild H, Kõiv T, Freiberg R, Nõges P, Nõges T. 2016. Algal diet of small-bodied crustacean zooplankton in a cyanobacteria-dominated eutrophic lake. PLoS ONE 11: e0154526.

Toporowska M, Pawlik-Skowronska B, Kalinowska R. 2014. Accumulation and effects of cyanobacterial microcystins and anatoxin-a on benthic larvae of Chironomus spp. (Diptera: Chironomidae). Eur J Entomol 111: 83-90.

Trinchet I, Cadel-Six S, Djediat C, et al. 2013. Toxicity of harmful cyanobacterial blooms to bream and roach. Toxicon 71: 121127.

Wacker A, Martin-Creuzburg D. 2007. Allocation of essential lipids in Daphnia magna during exposure to poor food quality. Funct Ecol 21: 738-747.

Wichard T, Gerecht A, Boersma M, Poulet SA, Wiltshire K, Pohnert G. 2007. Lipid and fatty acid composition of diatoms revisited: rapid wound-activated change of food quality parameters influences herbivorous copepod reproductive success. Chembiochem 8: 1146-53.

Cite this article as: Solis M, Pawlik-Skowrońska B, Adamczuk M, Kalinowska R. 2018. Dynamics of small-sized Cladocera and their algal diet in lake with toxic cyanobacterial water blooms. Ann. Limnol. - Int. J. Lim. 54: 6 